\title{
"The Red Plague Rid You For Learning Me Your Language!" - Standard and Non-Standard Use in English and in Portuguese
}

\author{
Rita Faria \\ (Universidade Católica \\ Portuguesa /CECC)
}

\section{Introduction: "The red plague rid you for learning me your language"}

n William Shakespeare's The Tempest, the knowledgeable Prospero arrives on an island with his daughter Miranda only to encounter its previous inhabitant, Caliban, presented as a brutish sort of man-monster (in fact, "not honour'd with/A human shape")

whom Prospero proceeds to enslave and educate. The relationship between the 'civilised' Prospero and the 'savage' Caliban is one of domination because Caliban's knowledge and consequent view of the world is shaped by Prospero's teachings, which include language. Part of Caliban's subjection to Prospero is that the latter taught him how to speak, and it is also language which determines Caliban's subsequent rebellion against Prospero. For the oppressed Caliban, rejecting the language imposed upon him is to reject the source of external power over his identity:

You taught me language, and my profit on't

Is I know how to curse. The red plague rid you

For learning me your language!

(The Tempest, Act I, Sc.2) 
This is Caliban's acknowledgement that learning a language that has been imposed by domination is in itself exertion of power and subjection to power - it is a process of 'otherisation' meant to cause alienation from a legitimate 'Self', in this case embodied in Prospero. It is also the acknowledgment that a language imposed by domination is foreign to our own nature, which forms an interesting nexus between language and nature - the language variety we speak reflects our nature. In $16^{\text {th }}$ century Portugal, Fernão de Oliveira remarked:

(...) cada um fala como quem é: os bons falam virtudes, e os maliciosos, maldades; os religiosos pregam desprezos do mundo e os cavaleiros blasonam as suas façanhas. (Oliveira 1975 [1536], 38)

This was of course in accordance with the spirit of the time and under the vast influence that Baldassare Castiglione's Il Cortegiano, published in 1528, exerted in European Renaissance:

Now it is the words themselves that make the greatness and magnificence of an oration; (...) But all this would be empty and of little moment if the thoughts expressed by the words were not fine, witty, acute, elegant, and solemn, according to the need. (Javitch 2002 [1528], 41)

Further, "to separate thoughts from words is to separate soul from body". (Javitch 2002[1528],40) What these judgements on language entail is a language ideology which associates 'appropriate' language to refinement of character. The ideology which presides to the establishment of a standard language is not too different, a standard language being "no more than a set of ideological norms that impose a certain linguistic variety as the one and only correct form of language." (Fairclough 2001, 27) Similarly, Trudgill emphasises that standard language (and Standard English in particular) is no more than a dialect which enjoys social prestige: "unlike other dialects, Standard English is a purely social dialect". $(1999,124)$

Before going any further, it is useful to define what a 'standard' language is and how it differs from 'non-standard' language, that is, 
dialects and sociolects (diatopic and diastratic varieties, respectively). We follow Crystal's clear definition of standard language:

(...) a prestige variety of language used within a speech community. 'Standard languages/dialects/ varieties' cut across regional differences, providing a unified means of communication, and thus an institutionalized norm which can be used in the mass media, in teaching the language to foreigners, and so on. (Crystal 2008, 450)

From Crystal's definition, it is clear that a standard language is a linguistic variety which differs from others due to the social prestige it enjoys. Dialects, or non-standard varieties, are those which differ from the norm due to regional or social factors: "A regionally or socially distinctive variety of language, identified by a particular set of words and grammatical structures." (Cyrstal 2008,142)

When deviation from the standard occurs due to social barriers, there is a distinction to be made between dialect and sociolect, the former usually determined by geographical lines and the latter based on social class, "a linguistic variety (or lect) defined on social (as opposed to regional) grounds, e.g. correlating with a particular social class or occupational group." (Crystal 2008, 440)

Non-standard language is therefore regionally and/or socially marked because it deviates from a conventionalised standard; Watts, for example, explains how Standard British English has historically worked as "a socially conscious language, a language of social exclusion, and a language of elite social values" $(1999,62)$ imposed by the education system. Because Standard is the only acceptable, correct norm, it eventually undermines and suppresses non-standard varieties. When discussing Standard English in the realm of education, Fairclough therefore wonders: "Is it possible to teach pupils a variety of English so much more prestigious and powerful than their own dialects or languages, without detriment to the latter?" $(1992,35)$

The aim of this paper is thus to examine how non-standard British English is translated into European Portuguese with a view to understand the social attitudes and ideologies embedded in 
standard and non-standard European Portuguese. We believe the translation of non-standard English into Portuguese is a perfect locus to provide an exploratory answer to this question as the translator is forced to take non-standard discourse into consideration. Doorslaer et al. point out that:

(...) a sense of nationality and ethnicity, with its attendant stereotyping, still informs our daily lives, and (...) remains an important criterion in categorizing human activity and cultural practices; (...) Cultural representations, including those of otherness, often use demarcation principles set out along geographical, regional, national or cultural lines. (Doorslaer et al. 2015, 1)

Translation of non-standard discourse needs to decide the extent to which it will reinforce or discard national and ethnic 'attendant stereotyping' and the cultural demarcation principles to which it will resort when finding suitable equivalents for non-standard discourse in the target language.

When discussing the translation of non-standard, it is important to note that the translator will most likely belong to an elite group who has had access to higher education, and is in all probability a speaker of standard language, that is, a 'legitimate speaker' of a 'legitimate language'. (Bourdieu 1991, to be discussed in the following section) The access or knowledge the translator may have of dialects can be limited to the extent that the translator will probably not be a speaker of dialect. In her book about politeness and class, Mills urges linguists to "move away from simply analysing middle class interactions"; $(2007,128)$ the translator can therefore decide to also "move away" from middle class discourse, traditionally associated to standard forms, and look for ways to adequately convey non-standard, non-elite discourse in the target language. It is for this reason that translation is important when trying to ascertain the extent to which we can speak of diatopic and diastratic variation in European Portuguese - because the translation of non-standard discourse plays with embedded ideological and social values which sometimes hide behind linguistic features; and it is therefore the job of the translator to decode those ideological values into a suitable rendition. 
Translating non-standard is therefore translating marginal discourse, the discourse of the 'Other' - it is translating Caliban. As Jansen explains, "the receiving culture, with its values, norm, traditions and self-images, has a decisive influence on the representation of the Other which is inherent in every translation activity" $(2015,166)$ - hence the particular importance of examining the translation of marginal, non-standard and non-elite discourse.

Section 2 of this paper will reflect on language and ideology and how these are particularly important in the realm of translation; section 3 will examine the corpus selected, that is, different literary works which resort to non-standard British English and the strategies employed in their translation into European Portuguese. Finally, section 4 will attempt to summarise the main conclusions to derive from different translation options and ideological stances towards standard and non-standard language.

\section{Ideology, Standard, Non-Standard and Translation}

The codification of a standard language and the resulting differentiation between standard and non-standard varieties are subjected to ideological values. Ideology is a set of "assumptions which directly or indirectly legitimise existing power relations." (Fairclough 2001, 27) It is "the tacit assumptions, beliefs and value systems which are shared collectively by social groups" (Hatim \& Mason 1997, 120) which lead to a normalisation of existing power relations - for example, the prestige or notions of correctness associated to a standard variety are very rarely called into question despite the fact that these are purely social criteria evoked to create a linguistic 'standardised' means of unification. "Standard language ideology" therefore defines the selection of a linguistic standard, imbued in a "particular set of beliefs about language." (Milroy 1999, 173) Such beliefs are that "there is one and only one correct spoken form of the language, modelled on a single correct form." (174) 
That a language ideology of domination of class (i.e., of elite groups over non-elite groups) presided over the codification and standardisation of British English, there is not much doubt:

Codification could be said to have become a weapon of class. What the codifiers had done, ultimately, was to propose and cultivate a code of linguistic forms which were in some degree different from those in use among the vast majority of the population. By analysing 'correct' usage in terms that only a tiny minority of educated people could command, the codifiers ensured that correctness remained the preserve of elite. (Leith 1997, 56)

This is not to say that there was a 'conspiracy' to dominate nonelite groups through language, as Leith rightly points out; rather, it is to say that the force of the ideology which states that there is such thing as a language variety more desirable and superior to others has presided over the need to establish a linguistic standard.

The ideology behind a standard language is therefore closely connected to the concepts of legitimate language and legitimate speaker defined by Pierre Bourdieu. The legitimate speaker not only produces grammatically coherent sentences, as Chomsky would put it, but goes beyond that - he or she performs a "social competence"; the legitimate speaker is "authorized to speak and to speak with authority." (Bourdieu 1991, 41) The authority derives, among other things, from the speaker's ability to speak the standard norm against which all other varieties are measured and irredeemably considered inferior. Standard language is therefore "a form of speech that is (virtually) universally recognized as legitimate, i.e. as the standard measure of the value of linguistic products." (Bourdieu 1991, 56) It is a language variety imbued with 'symbolic capital', a prestige and underlying power attached to it because it is universally considered to be more correct than other varieties. As Milroy puts it, "typically the standard-language ideology regards optional variation in either channel [written or spoken] as an undesirable deviation from a uniquely correct form". $(1999,175)$

The ideology underlying Standard European Portuguese is of course not too different from the elite social values which inform 
Standard British English. The utility of a standard variety to provide a means of linguistic unification of a country or nation lies precisely in the high social regard which most members of the linguistic community hold it. Cunha \& Cintra therefore define the standard of European Portuguese as "(...) conjunto dos usos linguísticos das classes cultas da região de Lisboa-Coimbra (...)."(1984, 10) (my emphasis) However, the dialectal variation of European Portuguese seems to be substantially different to British English. Due to the political configuration of the British Isles, Standard British English "exhibits significant social variation. Subsumed under Standard English (or Standard British English) are Standard English English (in England and Wales), Standard Scottish English and Standard Irish English." (Hughes et al. 2012, 13)

The linguistic variation of the British Isles is therefore of heteroglossia, that is, "the simultaneous use of 'languages' " and fundamentally "the coexistence of different competing ideological points of view, whether constitute in a single national 'language' or within the complex communicative repertoires in play in late modern societies." (Blackledge \& Creese 2014, 5) Heteroglossia, the coexistence of different social and regional linguistic varieties actively in use within one linguistic community, brings a number of societal consequences, first and foremost in education and what constitutes 'appropriateness' in language. Heteroglossia therefore emphasises "a struggle between social groups (...) for control of (or 'hegemony' over) its sociolinguistic order" (Fairclough 1992, 34) insofar as it forces a decision as to how far non-standard discourse can be 'tolerated' in the classroom.

Can the discussion of heteroglossia and ideological pressure on language be applied to the variation of European Portuguese? Maybe so, but the cultural and political configuration of Portugal is vastly different from that of the British Isles, which means that the diastratic and diatopic variations of European Portuguese are usually described as of limited dimension. For example, Ferreira et al. explicitly point out the relative homogeneity of European Portuguese: 
Apesar da relativa uniformidade e da reduzida diferenciação dialectal que caracteriza a língua portuguesa, quando comparada com outras línguas românicas, ela apresenta contudo variações diatópicas sobretudo a nível fonético mas também em todos os restantes níveis (fonológico, morfológico, sintáctico, lexical, semântico). (Ferreira et al. 1996, 491)

In fact, in 1974, Manuel de Paiva Boléo had already emphasised the "exceptional" homogeneity of the Portuguese language, which he attributed to the longevity of a country almost impervious to the introduction of foreign elements:

São várias as causas desta homogeneidade excepcional da língua portuguesa, homogeneidade que, com meu conhecimento, não tem paralelo em qualquer outra língua da Europa e que tanto contribui para a sua vitalidade. Apontarei somente as causas que me parecem mais importantes: Em primeiro lugar, o ser Portugal um dos mais velhos países da Europa. (...) Em segundo lugar, os elementos estrangeiros que (...) se integraram na sua população constituem uma ínfima maioria. (Boléo 1974, 260)

What Boléo considers of great variation in European Portuguese is lexicon, given the vast wealth of regional, non-standard vocabulary. This variation constitutes such a deviation from Standard, and is so regionally marked, that the "educated Portuguese" has in fact no idea of exactly how diverse Portuguese lexicon can be. ${ }^{1}$ This is an interesting remark because it implies that there are indeed demarcating cultural, linguistic lines shaping the elite discourse of the "educated Portuguese" and those of the non-elite, non-standard, socially and/ or regionally marked discourse of those Portuguese speakers who, for the lack of a better term, are not "educated Portuguese".

So far, there is recognition that Portuguese, like any other language, varies, although that variation seems restricted. For example, Cintra categorises European Portuguese dialects based on regional phonetic

1. "O português, mesmo instruído, não faz a menor ideia da variedade lexical da sua língua." (Boléo $1974,264)$ 
features which grant some dialects "strong phonetic personalities", $(1970,190)$ but not a wide social variation. This is not to say, however, that this language knows no heteroglossia and is of reduced social variation. It is to say that the social variation of European Portuguese might not have had much discussion or have been granted much attention thus far. This begs the question - how is socio-regional variation manifested, in particular social variation determined by social class and societal pressures? Mills reinforces the need to focus on how social context and ideologies pressure language so as to gear it into what is in fact an elite norm, whilst other linguistic behaviours tend to be classified as "deficient". $(2017,1)$ The pressure of social context and ideology in the use of European Portuguese is something that needs to be taken into account, despite the fact that the configuration of social class and social grouping is necessarily different in Portugal and in the UK.

This paper will not provide a straightforward answer to aforementioned questions but it will attempt to provide an exploratory answer by examining translations of literary works in which non-standard, non-elite discourse is of paramount importance to the plot and to the characters' identity. Translating such works means that whether opting for standard language or not, the translator has to take into account "the ideological thrust" (Hatim \& Mason 1997, 89) of non-standard features in the source text. There is a myriad of options, depending on how source-oriented the translation is and how much the "legitimate rights" of the source text (Toury 1995, 31) should or can be upheld. Therefore, the adequate translation of non-standard variation depends on how much the translator wants a translation of "resistance" to standard and chooses a foreignising effect; (Venuti 2008) or how desirable the translator finds a domesticated, conservative translation, in which case the resort to standard would be close to "un style zéro". (Lambert apud Hatim \& Mason 1997, 66) None of these options is easy; as Berman puts it, "a vernacular clings tightly to its soil and completely resists any direct translating into another vernacular". While noting that "the effacement of vernaculars is thus a very serious injury to the textuality of prose works", he also draws attention to a laughable effect which may arise from attempts at 
translating dialect variation: "An exoticization that turns the foreign from abroad into the foreign at home winds up merely ridiculing the original". $(2000,309)$ Ghassempur states that "the best compromise seems to be the translation of a dialect into a supraregional colloquial language that is universally understood by readers in the target language". $(2011,54)$ Whilst this seems a reasonable proposition, it is not entirely certain that it will avoid the "ridiculing" effect to which Berman fundamentally draws attention.

In order to establish how ideologically close to, or far from, standard discourse the European Portuguese translation of non-standard British English chooses to position itself, all the works selected comprised non-standard forms essential to the idiolect of the literary text: The Waste Land (1922) by T. S. Eliot, an excerpt; Lady Chatterley's Lover (1928) by D. H. Lawrence; 1984 (1949) by George Orwell; and A Clockwork Orange (1962) by Anthony Burgess.

The corpus selected could, of course, have been comprised of different literary works, given the variety of non-standard language used in British literature. However, because the choice had to be limited for the purposes of this paper, our selection criteria were mainly two: firstly, non-standard language had to be the driven force behind characters' identity (as evidenced in the excerpt from The Waste Land and mainly in Lady Chatterley's Lover) and/or play a fundamental role in advancing the plot (which is evident in 1984, where the use of non-standard is crucial to define the societal division into rigid echelons which are indispensable to the fictional world of the novel). The reasons for the choice of A Clockwork Orange will be provided in its respective section. The second criterion had to do with the pluricentric nature of both English and Portuguese, that is, "languages with several interacting centres, each providing a national variety with at least some of its own (codified) norms." (Clyne 1992, 1) Because we wanted to explore how translation into European Portuguese reveals the ideologically charged nature of the standard - non-standard division, it was imperative to keep linguistic coherence in the corpus and to examine works from the "inner circle" of both English and Portuguese, rather than "outer or extended circles." (Crystal 2003, 60) The "inner circle" of a language 
(albeit mostly applied to English) comprises the "traditional basis" of a language which, in the case of English, means UK, USA, Australia and New Zealand. European Portuguese is also an "inner circle" variety of Portuguese and thus, for coherence in the corpus to be achieved, we selected literary works which resort to non-standard features within inner-circle English and Portuguese.

\section{Translating the corpus}

3.1. The Waste Land by T. S. Eliot [1922]

In part II of The Waste Land, "A Game of Chess", we are introduced to the conversation of two women in the pub. Their discourse is clearly socially marked by colloquialism and vernacular, ${ }^{2}$ that is, by non-standard features which allude to their non-elite, marginal life in the fringes of society:

When Lil's husband got demobbed, I said -

I didn't mince my words, I said to her myself,

HURRY UP PLEASE IT'S TIME

Now Albert's coming back, make yourself a bit smart.

He'll want to know what you done with that money he gave you

To get yourself some teeth. He did, I was there.

You have them all out, Lil, and get a nice set,

He said, I swear, I can't bear to look at you.

And no more can't I, I said, and think of poor Albert,

He's been in the army for four years, he wants a good time,

And if you don't give it him, there's others will, I said.

Oh is there, she said. Something o'that, I said.

Then I'll know who to thank, she said, and give me a straight look. (...)

You ought to be ashamed, I said, to look so antique.

(and her only thirty one.)

2. As defined by Crystal, vernacular refers "to the indigenous language or dialect of a speech community". $(2008,511)$ 
I can't help it, she said, pulling a long face,

It's them pills I took, to bring it off, she said.

(...)

You are a proper fool, I said.

Well, if Albert won't leave you alone, there it is, I said,

What you get married for if you don't want children?

(..)

HURRY UP PLEASE IT'S TIME

HURRY UP PLEASE IT'S TIME

Goonight Bill. Goonight Lou. Goonight May. Goonight.

Ta ta. Goonight. Goonight.

Good night, ladies, good night sweet ladies, good night, good night.

Quando o marido da Lil saiu da tropa, eu disse -

Não tive papas na língua, fui eu mesma que lhe disse,

VAMOS EMBORA POR FAVOR ESTÁ NA HORA

Agora que o Albert vem aí, vê lá se te pões jeitosa.

Há-de querer saber o que fizeste ao dinheiro que te deu

Para te pores uns dentes. Deu-te, sim, eu estava lá.

Trata de tirá-los todos, Lil, arranja uma dentadura bonita,

Disse ele, juro, nem sequer aguento olhar para ti.

E já nem eu aguento, disse eu, e pensa no pobre do Albert,

Quatro anos de tropa, agora há-de querer desforra,

E se tu não lha dás, há outras que sim, disse eu.

Ai há, disse ela. Olha o que te digo, disse eu.

Então já sei a quem agradecer, disse ela, e olhou-me nos olhos. (...)

Devias ter vergonha, disse eu, de parecer um caco velho.

(E ela só com trinta e um.)

Não sei o que fazer, disse ela, a pôr cara de caso,

É dos remédios que tomei, para o desmancho, disse ela.

(...)

Tu és mesmo parva, disse eu.

Então, se o Albert não te deixa em paz, lá está, disse eu,

Para que te casaste se não queres ter filhos? 
(..)

VAMOS EMBORA POR FAVOR ESTÁ NA HORA

VAMOS EMBORA POR FAVOR ESTÁ NA HORA

Banoite Bill. Banoite Lou. Banoite May. Banoite.

'Deuzinho. Banoite. Banoite.

Boa noite, senhoras, boa noite, gentis senhoras, boa noite, boa noite.

(The Waste Land, part II, "A Game of Chess") (my emphasis)

The target text clearly recognises and acknowledges the non-standard source text and shows clear attempts at maintaining the deviation from the standard mainly by finding equivalents to colloquial vocabulary. This is obvious in the translation of idiomatic phrases such as "I didn't mince my words" - "não tive papas na língua"; "make yourself a bit smart" - "vê lá se te pões jeitosa"; "You ought to be ashamed, I said, to look so antique" - "devias ter vergonha, disse eu, de parecer um caco velho"; "I can't help it, she said, pulling a long face" - "Não sei o que fazer, disse ela, a pôr cara de caso". The phonetic elisions are also respected as much as possible - "Goonight" - "banoite; ta ta" - "'deuzinho", although no equivalent was found for "something o'that" - "olha o que te digo".

It is in the non-standard syntax that the translation appears to be more reticent. This excerpt of The Waste Land exhibits marked dialectal features at syntax level such as:

Elision of auxiliary verbs ("He'll want to know what you done with that money he gave you; What you get married for if you don't want children?") which follows a tendency in many dialectal varieties of British English to "bring the irregular verbs into line with the regular ones, the distinction being signalled only by the presence or absence of have." (Hughes et. al. 2012, 27) In Portuguese, these forms are rendered in perfect Standard - "Há-de querer saber o que fizeste ao dinheiro que te deu; Para que te casaste se não queres ter filhos?"

Double negative: interestingly enough, the reason why double negatives are so common in non-standard discourse and excluded from Standard English is because "it is in fact the standard dialect which has diverged from the other varieties, not the other way 
around." (Hughes et. al. 2012, 25) "And no more can't I - e já nem eu aguento", again rendered in Standard Portuguese.

Precedence of direct object pronoun over indirect object (Hughes et al. 2012, 20): "And if you don't give it him, there's others will, I said". (my emphasis) Again, the Standard variety is chosen in the Portuguese translation: "E se tu não lha dás, há outras que sim, disse $\mathrm{eu}^{\prime \prime}$. In Portuguese, the following complex standard structures are to be noted: contraction of indirect and direct object pronouns "he $+\mathrm{a}=\mathrm{lha}$ "; standard placement of object pronoun before the verb, as commanded by the negative particle "não" ("e se tu não lha dás").

Object pronoun "them" in lieu of demonstrative pronoun "those: It's them pills I took -- É dos remédios que tomei", a Standard Portuguese sentence with no deviation into non-standard syntax.

In conclusion, and although the translation of "A Game of Chess" does not entirely obliterate dialect markers nor does it use standard throughout, it is nevertheless much closer to the standard norm than the source text, and tends to use standard syntax to convey conspicuous deviations from standard in the source language. Given that the translator demonstrably does not wish to shy away from finding suitable equivalents to maintain the 'foreignising' effect of non-standard, what this translation seems to convey is that European Portuguese may lack the means to render non-standard linguistic features with a degree of diastratic variation approximate to the source text.

\subsection{Lady Chatterley's Lover by D.H. Lawrence [1928]}

In Lady Chatterley's Lover, Lady Constance, married to Sir Clifford Chatterley, meets and falls in love with groundkeeper Oliver Mellors. She eventually decides to leave her husband for him, in a complicated legal divorce procedure. The love affair between Constance and Mellors is troubled not only because they are both married, although Mellor's wife has left him and he admittedly "hates" her; but also because theirs is a class difference: whereas Constance has married into English aristocracy, Mellors is a working-class, East-Midlands, 
Nottingham dialect speaker. The interesting thing about Mellors is his "bi-dialectalism" (Leith 1980, 254) responsible for his occasional code-switching. Having learned "fine" English, he chooses to speak his local dialect so as to fight his loneliness and somehow connect to the world around him. For Mellors, dialect is identity, a "badge of his masculinity" (Leith 1980, 254) that allows him to resist submission to the established social order, as Christie also notes:

(...) the depiction of Mellors' speech using eye-dialect tends to occur only in cross-gender dialogue, and particularly when he is resisting the power imbalance inherent in his relationship with Connie. To this extent, Lawrence could be seen as drawing on the ideology that regional speech bestows a covert prestige related to masculinity (...). (Christie 2007,124)

There are many instances of the use of dialect in the novel. In most of them, the translator uses standard throughout, with an indication at narrative level that Mellors speaks dialect, similar to a footnote. For example:

'Tha mun come one naight ter th' cottage, afore tha goos; sholl ter?' he asked, lifting his eyebrows as he looked at her, his hands dangling between his knees.

- Tens de vir uma noite à cabana antes de te ires embora, está bem? - perguntou, com as sobrancelhas levantadas e as mãos caídas entre os joelhos.

Falava em dialeto. (Lady Chatterley's Lover, Chapter 12) (my emphasis)

The deviation of forms of address in Mellor's dialect as opposed to address in Standard English is equally relevant ("Tha mun come..."). In the East-Midlands dialect employed in the novel, linguistic address keeps the distinction between $\mathrm{T}$ (informal/familiar) and V (formal/ 
distant) address pronouns (Brown \& Gilman 1968) ${ }^{3}$ which has been completely eliminated from Standard English. The pronouns "thee" and "thou" (contracted to "tha" in Northern varieties for both subject and object positions) (Hughes et al. 2012, 35) and "thine" are thus frequently employed by Mellors as his familiarity with Constance progresses - much to Constance's dislike. This allows for a convenient translation in Portuguese, a language which maintains a $\mathrm{T} / \mathrm{V}$ opposition in terms of linguistic address. It would be important that the translation keep the $\mathrm{T} / \mathrm{V}$ distinction as a dialectal feature which Constance finds heavily marked; the Portuguese rendition solves the problem by attaching such markedness to the familiar pronoun " $t u$ ":

He laughed a little, half bitter, half amused.

'It isna horrid,' he said, 'even if tha thinks it is. An' tha canna ma'e it horrid. Dunna fret thysen about lovin' me. Tha'lt niver force thysen to 't. There's sure to be a bad nut in a basketful. Tha mun ta'e th' rough wi' th' smooth.' (...)

She hated the dialect: the thee and the tha and the thysen.

Ele riu-se, semi-divertido, semi-azedo.

- Não é assim tão mau continuou - embora pareça. És tu que achas que é pior do que é. Não te importes se me amas ou não. Não podes forçar-te. Num cesto de nozes há sempre uma podre. É preciso tirar a podre das boas. (...)

Odiava o dialeto e os "tus" dele. (Lady Chatterley's Lover, Chapter 12) (my emphasis)

Again, the reference to dialect is conveyed at narrative level only and eliminated from direct speech. Despite the effort to transfer the social markedness of the pronouns of address "thee, tha, thysen" onto

3. Brown \& Gilman put forward a binary T/V distinction concerning address pronouns, whereby T forms of address apply to "familiar" circles and V forms of address are used in formal circles requiring "polite" address. The usage of T/V forms is prescribed by two dimensions, the "power semantic" and the "solidarity semantic". The power semantic, which was pervasive until the 19th century, is nonreciprocal and asymmetric and determines that the superior says $\mathrm{T}$ but receives $\mathrm{V}$ from the inferior; the solidarity semantic establishes the reciprocal usage of $\mathrm{T} / \mathrm{V}$ forms, whereby solidarity or lack thereof (social distance) determines linguistic address and overrides power; superiors and inferiors exchange $\mathrm{V}$ forms equally; solidary equals exchange mutual $\mathrm{T}$ forms. 
the pronoun "tu", Constance addresses Mellors by resorting to $3^{\text {rd }}$ person verb forms and the pronoun "você", and switches to "tu" in more intimate moments. Some examples follow:

Mas quando ele ia a levantar-se, ela agarrou-o em pânico.

- Não, não, não se vá embora, não me abandone. Não se zangue comigo! Abrace-me, abrace-me com força! - murmurava ela, num frenesim, sem saber o que dizia, abraçada a ele com todas as suas forças. ( $O$ Amante de Lady Chatterley, Chapter 12) (my emphasis)

Further ahead, in the same chapter (my emphasis):

- Onde estás? Onde estás? Fala comigo. Diz qualquer coisa! (...) Amas-me? - murmurou ela.

Later on in the novel, when conventional social relations are resumed, Constance (and indeed Mellors) reverts to $3^{\text {rd }}$ person singular address forms:

- Bebe cacau ou chá ou café? - perguntou ele.

- Não me apetece tomar nada - respondeu ela, olhando para a mesa. Mas coma você. (O Amante de Lady Chatterley, Chapter 14) (my emphasis)

In view of this, the impact of rendering the social stigma of the non-standard T/V distinction in English is attenuated. Firstly, because the T/V pronominal distinction is part of Standard Portuguese; secondly, because Constance varies her address of Mellors according to intimacy, resorting to $\mathrm{T}$ forms for intimate moments and $\mathrm{V}$ for socially conventionalised moments. Thus, $\mathrm{T} / \mathrm{V}$ pronouns in the Portuguese translation are used to nuance the complexities of Constance's feelings towards Mellors and do not convey non-standard discourse only. 
As a result, the full impact of the non-standard $\mathrm{T} / \mathrm{V}$ distinction in the source text ${ }^{4}$ is softened in the translation.

In instances when the source text forces the translator to find an equivalent to non-standard discourse at dialogue level, the option is again one of moderating dialectal marks, resorting to simply eliminate parts of the dialogue and to indicate dialect at narrative level (signalled in bold below). The crossed-out text in the following excerpt indicates parts which were altogether eliminated in the translation:

'Sholl ter?' she echoed, teasing.

He smiled.

'Ay, sholl ter?' he repeated.

'Ay!' she said, imitating the dialect sound.

'Yi!' he said.

'Yi!'she repeated.

'An' slaip wi' me,' he said. 'It needs that. When sholt come?'

when sholl I?' she said.

'Nay, he said, 'tha canna do't. When sholt come then?'

"Appen Sunday,' she said.

"Appen a' Sunday! Ay!'

He laughed at her quickly.

'Nay, tha canna,' he protested.

'Why canna I?' she said.

He laughed. Her attempts at the dialect were so ludicrous somehow.

'Coom then, tha mun goo!' he said.

'Mun I?' she said.

'Maun Ah!' he corrected.

'Why should I say maun when you said mun?' she protested. 'You're not playing fair'

'Arena Ah!' he said, leaning forward and softly stroking her face.

4. It should nevertheless be noted that resorting to pronouns of address to show some attempt at rendering non-standard discourse is an important strategy in which the translation of Lady Chatterley's Lover is not alone, as we shall see when examining the Portuguese version of 1984 . 
- Está bem - respondeu Connie, imitando o dialeto nas respostas seguintes.

- E dormirás comigo? É necessário. Quando vens?

- Talvez no domingo.

- Está bem, no domingo.

Ele troçava.

- Não consegues imitar-me.

- Porquê?

Ele ria. Ela era cómica a imitar o dialeto.

- Bem, temos de nos ir embora.

- Eu tenho? - disse ela.

- Ê tenho! - corrigiu ele.

- Porque devo dizer ê em vez de eu? - protestou ela. - Não estás a ser justo.

- Então ê não estou a ser justo? - disse, inclinado sobre ela e fazendo-lhe festas na

cara. (Lady Chatterley's Lover, Chapter 12) (my emphasis)

When absolutely forced to find an equivalent for "maun ah (must I)" or "Arena Ah (aren't I)", the translator chooses the phonetic reduction of the pronoun " $\mathrm{eu}^{\prime \prime}$ - " $\hat{\mathrm{e}}$ " so as to convey the linguistic intricacies of Mellor's dialect.

The explanation for the very clear choice of standard in the target language must be understood in the light of other features of this particular translation, particularly taboo words, which are also eliminated and replaced with standard discourse. In fact, the translation dates from 1975 and the 2016 edition is a reprint, which may explain its domestication; it may indeed constitute a "sign of the times" since we can only imagine that in 1975 "the normative pressures of linguistic practices" (Erkazanci-Durmus 2011, 30) in Portugal were greater and thus a conservative, normalised translation might have been preferable. 


\subsection{4 by George Orwell [1949]}

1984 is about a dystopian future where the State (embodied in the elusive figure of Big Brother) surveys citizens' every move and keeps them tightly stratified into different social groups with a different set of social rights and duties, noticeable in every detail, from the uniform they wear, to where they live, to the language variety they speak. The protagonist Winston, decidedly "middle class", if such definition can be applied to the world of 1984 , is conspicuously different from "the proles", the working class or proletariat confined to specific neighbourhoods and constricted living standards. In the novel, the class difference between Winston and the proles is definitely conveyed through use of language, Winston speaking standard British English and the proles with whom he occasionally interacts speaking a variety of non-standard English close to cockney.

The Portuguese translation seems to have opted for the aforementioned "supraregional colloquial language" inasmuch as it conveys non-standard discourse by means of phonetic contractions largely connected to informal uses but not to a particular regional variety, ${ }^{5}$ as illustrated in the following example:

5. The option of rendering non-standard sociolects by resorting to a regional variety is followed in the Portuguese translation of Pygmalion, as explained by the translator:

Não existe em Portugal nenhuma cidade de certa importância que possua uma linguagem tão característica como acontece com a parte de Londres onde se falava (mais do que se fala hoje) o cockney. (...) Por essa razão, achei por bem optar por pô-las [as personagens] a falar aproximadamente segundo o padrão dialectal das Beiras, embora por vezes se possam encontrar expressões de outras áreas e até mais tipicamente de Lisboa (como a forma verbal "hadem" por "hão-de", muito usada em Lisboa, embora não só). (Shaw s/d,14)

It is interesting to note that choosing a regional variety (which is eventually peppered by borrowing from other dialects, as the translator explains) is also a form to convey sociolectal variation insofar as it reinforces the standard dialect from coastal, central Portugal as the educated measure against which all other varieties are compared. Hatim \& Mason disagree with the option followed by the Portuguese translation as it conveys a general tone of defiance while failing to render Eliza's general insecurity and social stigma caused by her idiolectical features:

Preserving the function of Eliza's idiolectal use may thus have to be informed by the 'human' or 'socio-geographical' criterion, rather than a purely 'locational' one (...). The translation of Pygmalion must therefore seek to bring out Eliza's socio-linguistic 'stigma', a communicative slant which, incidentally, should not necessarily entail opting for a particular regional variety and could as effectively be relayed through simply modifying the standard itself. (Hatim \& Mason 1997, 89) 


\section{ESTUDOS / ESSAYS}

“"Yes," I says to 'er, "that's all very well," I says. "But if you'd of been in my place you'd of done the same as what I done. It's easy to criticise," I says, "but you ain't got the same problems as what I got."

'Ah,' said the other, 'that's jest it. That's jest where it is.'

- "Pois é", disse-lh'eu, "isso é tudo muito bonito", foi mesmo o qu'eu lhe disse. "Mas se 'tivesses no meu lugar fazias o mesmo qu'eu fiz. É muito fácil criticar", diss'eu, "mas tu é que não tens os mesmos problemas qu'eu tenho".

- Ah - disse a outra --, é isso mesmo. É assim mesmo qu'as coisas são. (1984, Chapter 8)

The source text displays phonetic and syntactical variation close to cockney which in the target language is rendered mainly by phonetic contractions:

h-dropping and first person subject agreement with third person verb form (in bold): I says to 'er - disselh'eu

replacement of the auxiliary to have with preposition of: but if you'd of been in my place you'd of done the same - Mas se 'tivesses no meu lugar fazias o mesmo $q u^{\prime} e u$ fiz

replacement of negative periphrasis with the contraction ain't: you ain't got the same problems as what I got - tu é que não tens os mesmos problemas qu'eu tenho.

By resorting to phonetic contractions across the board in order to convey heavily marked non-standard, phonetic and syntactical features, the target language does manage to convey a clear vernacular colouring. Similarly to the translation of The Waste Land, this "colouring" is closer to Standard Portuguese than the source text is to Standard English. Despite the clear attempts at translating dialect, the subliminal sway of standard language is present and noticeable in instances when the translator creates a truly heteroglossic discourse by mixing diastratic linguistic features with clear markers of Standard Portuguese: 
It was Boat Race night - terribly rowdy they used to get on Boat Race night - and I bumps into a young bloke on Shaftesbury Avenue. Quite a gent, 'e was - dress shirt, top 'at, black overcoat.

Foi na noite da Regata (eles gostavam sempre de armar barulho nas noitas da Regata), eu dera um encontrão a um rapazote, na Shafesbury Avenue. Ia todo bem-posto, o tipo: camisa engomada, cartola, casaca preta. (1984, Chapter 8)

Considerable non-standard features such as first person subject agreement with third person verb form (I bumps), elision of initial $h$-sound ('e was, top 'at), colloquial vocabulary (young bloke, quite a gent), and subject - object inversion (quite rowdy they used to get) are rendered by simply resorting to colloquial vocabulary (armar barulho, rapazote, ia todo bem posto, o tipo). Furthermore, the Portuguese rendition uses the "Pretérito Mais Que Perfeito" dera (eu dera um encontrão a um rapazote), roughly equivalent to the Past Perfect in this context, which I venture to guess is relatively rare in either standard or non-standard spoken Portuguese, which usually prefers the periphrasis tinha dado. The employ of dera, whilts it may seem a mere detail, is in fact an important reminder of the "subliminal sway" of standard language encountered in the translations of dialect.

It is also relevant to examine how linguistic address in the source text has been rendered in European Portuguese. In fact, the translation of 1984 presents instances where the choice of forms of address is completely dependent on how the translator interprets the social, ideological meanings of the source text, namely the power play between Winston and the proles. In the following example, Winston is in a pub frequented by the proles and initiates a conversation with an older man. Winston wishes to know how life was before "the Party" and therefore repeatedly addresses the old man to urge him to answer his questions in a straightforward manner: 
'You must have seen great changes since you were a young man' said Winston tentatively. (...)

'The beer was better,' he said finally. 'And cheaper! When I was a young man, mild beer - wallop, we used to call it - was fourpence a pint. That wa before the war, of course.' (...)

'You are very much older than I am,' said Winston. 'You must have been a grown man before I was born. You can remember what it was like in the old days, before the Revolution. People of my age don't really know anything about those times.

- Você já deve ter assistido a grandes mudanças, desde novo - disse Winston, sondando o terreno. (...)

- A cerveja era melhor - acabou por dizer. - E mai'barata! Quand'eu era novo, um quartilho da cerveja mais leve (e bem boa ela era!) custava quatro dinheiros. Isto, antes da guerra, é claro. (...)

- Você é muito mais velho do que eu - disse Winston - Ainda eu não era nascido, já você devia ser um homem feito. Lembra-se com certeza dos tempos, antes da Revolução. As pessoas da minha idade, no fundo, não sabem nada dessa época. (1984, Chapter 8) (my emphasis)

The use of the pronoun of address você is of unclear meaning given the myriad of functions this pronoun can perform in European Portuguese and, more importantly, given the fact that the use of você seems to be determined by both regional and social factors. The diatopic and diastratic variation of você is imprecise insofar as it is used by both elite and non-elite groups throughout the country, albeit with different meanings. Cintra (1986), in what remains a fundamental study of forms of address in Portugal, defines você as a solidarity pronoun. ("de igual para igual" - Cintra 1986, 14) A similar view is shared by Cuesta \& Luz, who define você as appropriate address between equals and explain that the reason why você seems to be gaining ground amongst Portuguese forms of address is precisely because it allows for a convenient, solidarity-governed address: 
Equivalente a este tratamento - e em geral traduzível em espanhol por 'tú' - é o de você (contracção de Vossa Mercê), que pela sua maior simplicidade vai dia a dia ganhando terreno. (Cuesta \& Luz 1971, 483)

However, the authors are quick to point out the social markedness of você:

Todavia, nalguns sítios mais arcaizantes do país você é considerado pelo povo como de certo modo depreciativo, utilizando-se a forma antiga vossemecê com as pessoas a que se deve um pouco de respeito. (Cuest \& Luz $1971,483)$

It is interesting to note that the translation of 1984 exhibits a usage of vossemecê which follows the social lines to which Cuesta \& Luz allude. To note the address forms in the following scene from Chapter 8 , when the barman addresses the old man to whom Winston is chatting and feels he owes him some sort of "respectful" (albeit slightly paternising) address:

'I likes a pint,' persisted the old man. 'You could'a drawed me off a pint easy enough. We didn't ave these bleeding litres when I was a young man.'

'When you were a young man we were all living in the treetops' said the barman, with a glance at the other customers. (...)

- Eu cá gosto é de quartilhos - insistiu o velho. - Não custava nada tirares um quartilho. Não havia nada destas porcarias destes litros quando eu era novo.

- Quando vocemecê era novo ainda a gente vivia em cima das árvores - disse o barman, lançando uma olhadela aos outros fregueses. (...) (1984, Chapter 8) (my emphasis)

This is a socially marked use of vossemecê insofar as the latter works as a discursive marker to show respect in non-elite discourse. Although vossemecê is still in use in very specific parts of the country to signal respect (in certain regions of Northern Portugal, vossemecê is an 
acceptable $\mathrm{V}$ form from grandchildren to grandparents, for example), it is the form você which has been largely disseminated. In line with previous works about the use of this form of address, Teyssier (1989) reinforces você as solidarity address and even as familiar address:

Mas o tratamento de familiaridade mais geral é você, no plural, vocês. Está reservado aos amigos, aos colegas, aos íntimos, p. ex., Você não deve zangar-se por eu lhe dizer isto. (Teyssier 1989, 129)

What can be gleaned from the literature available is that voce is adequate solidarity address for interactions between equals. However, perhaps because the definition of "equality" might be difficult in itself, você is undoubtedly ridden with a certain social sigma when used simply as address between mutually unfamiliar participants. The solidarity semantic, which no doubt happens in familiar circles and allows for the use of $\mathrm{T}$ forms such as $t u$ and to a certain extent você, is on shakier grounds between socially distant participants. This is because, as Cintra (1986) explains, você not only lends itself to reciprocal address between equals, but also to non-reciprocal address from superior to inferior; and because, as Cintra (1986) further ellucidates, European Portuguese has never found an adequate pronominal replacement for the loss of the pronoun of address vós.

The social meanings encoded in você seem to be simply too complex to allow for a smooth, uncontroversial use of this form of address. Oliveira therefore states that "many speakers consider você offensive and so avoid it altogether" $(1994,26)$ and recommends that "foreigners should not initiate você but may reciprocate." (48) (emphasis in the original) Duarte is even clearer concerning the inherent problems in the diastratic variation of você: 
Com efeito, o pronome «você» (...) coloca muitos problemas na variedade europeia do português, porque, no singular, só é aceitável em certas regiões e em certas variedades diastráticas, sendo o seu uso na variedade padrão muito específico de certas relações absolutamente simétricas e amistosas e inaceitável na maior parte dos casos, sobretudo sempre que exista dissimetria social ou de idade entre os interlocutores. Nas variedades mais próximas da norma, o "você» é quase inadmissível, geralmente sentido como grosseiro ou, pelo menos, pouco cortês. (Duarte 2011, 87)

Finally, Gouveia encapsulates the problematic definition of você as a social marker of imprecise borders when he points out the following:

... a quase generalização do uso de você em vez de o Senhor, a Senhora (...) ou ainda o facto de (...) não se chegar facilmente a um consenso relativamente à definição e descrição dos contextos de uso de você e das variáveis sociais a eles associados. (Gouveia 2008, 94)

To go back to the translation of 1984 and the usage of você - given the imprecise use of this form and the wide social variation which governs it, it is not entirely clear why the translator has chosen this form of address. It can simply be because it is part of the translator's own idiolect and seems adequate to render address among socially distant interlocutors, although the clear social superiority granted to Winston is undeniable. Therefore, and considering there are no other instances in the novel where você is used, it is very possible that the translator was rendering the power imbalance between the old man and Winston by resorting to a non-reciprocal você. The latter is therefore an added pragmatic layer to the translation to convey something that in English is rendered by the contrast between non-standard English (as employed by the old man) and standard English (as employed by Winston). It should be noted that in the Portuguese translation the old man uses third-person verb forms to address Winston and never resorts to você; and that further ahead in the novel, in a conversation between Winston and shopkeeper Mr Charrington, Winston addresses him by third-person verb forms and Mr Charrington uses o senhor: 


\section{ESTUDOS / ESSAYS}

The old man had grown noticeably more cheerful after receiving the four dollars. Winston realized that he would have accepted three or even two.

'There's another room upstairs that you might care to take a look at,' he said. 'There's not much in it. Just a few pieces. We'll do with a light if we're going upstairs.

$\mathrm{O}$ velho ficara visivelmente mais alegre desde que recebera os quatro dólares. Winston percebeu que ele se teria contentado com três, ou mesmo com dois.

- Há lá em cima outra sala que talvez o senhor também queira ver disse. - Não tenho ali grande coisa. Só meia dúzia de peças. Bem, mas para irmos lá acima vamos precisar de luz. (1984, Chapter 8)

Similarly to The Waste Land, the 1984 translation attempts to resist domestication but is much closer to Standard Portuguese than the source text is to Standard English. Instead, it resorts to phonetic contractions, colloquialism and pragmatic manipulation of forms of address as some form of "stylistic compensation" (Ghassempur 2011) for its relative distance from non-standard linguistic features.

\subsection{A Clockwork Orange by Anthony Burgess (1962)}

A Clockwork Orange exhibits a daring, provocative use of English mixed with Russian so as to convey the mind-set of the protagonist Alex, a violent fifteen year-old misfit who, together with friends of a similar age, is devoted to chaos and to brutal crime. Burgess describes the idiolect he creates for Alex as "a mixture of Russian and demotic English, seasoned with rhyming slang and gipsy argot." (Burgess 2007, 5) He also resorts to the Russian suffix nadsat, meaning - teen, to designate the new language created for Alex and his "droogs", his "friends in violence". The use of non-standard in A Clockwork Orange is therefore not a diatopic or diastratic language variety used by a particular community. It is instead a highly creative, inventive literary language where 
vocabulary is twisted and pushed to its boundaries in order to endow Alex with an idiolect ${ }^{6}$ capable of conveying his own twisted, boundary-pushing behaviour, that is, capable of conveying a "youthful free will having the choice of good and evil although generally choosing evil." (Burgess 2007, 4) Nadsat is therefore not a mere linguistic variety which deviates from Standard English - it is effectively used in opposition to Standard English so as to convey a marginal, brutal protagonist against any kind of social order. As Erkazanci-Durmus puts it, Nadsat is an actual "anti-language". $(2011,27)$

The translation of idiolect in A Clockwork Orange posits numerous challenges, mainly because the creativity embedded in language is part of the novel's literary style and achievement. To simply gloss over or tone down non-standard features is simply not an option; moreover, resorting to a regional variety or a "supraregional" colloquial variety is an undesirable strategy, since Alex's idiolect is indeed something unique, spoken by him and his friends only. Finding adequacy for his discursive features in regional varieties in the target language proves to be a difficult task.

The Portuguese translation therefore chooses to maintain the full foreignising effect of Alex's discourse by attempting to recreate Nadsat in Portuguese. Nadsat is very much based on re-lexicalisation, that is, "the production of new vocabulary (...) or the adaptation of an existing word (...) to clearly show that a shift or reversal of values has occurred." (Erkazanci-Durmus 2011, 28) Therefore, the options in the target language are to recreate the non-standard effect by mixing Portuguese and Russian vocabulary; or to recreate the foreignising effect of Nasdat by means of morphological manipulation of lexicon in order to render the Russian-English vocabulary as Portuguese neologisms. It is the latter option that the Portuguese translation follows, reproducing the re-lexicalisation on which Nadsat is based by creating vocabulary in Portuguese which reflects the Russian-English effect of the source language. Illustrative examples are "Appy polly loggy"

6. As defined by Cristal, "one's personal dialect". $(2008,235)$ The fact that Alex is endowed with his unique discursive style, not marked by features which can be generalised as part of a wider dialect, is of paramount importance to the translation, as we shall see. 
(apology), rendered in the translation as "diz-que-culpa"; and the adjective "horrorshow" rendered as "horrorochoso", which equally evokes the image of ostentatious violence of the source language:

\footnotetext{
We wore our hair not too long and we had flip horrorshow boots for kicking.

Usávamos o cabelo não muito comprido e calçávamos umas botas todas horrorochosas para andar ao biqueiro. (A Clockwork Orange, Chapter 1)
}

The Russian effect is kept inasmuch as it is kept in the source language, which the translation attempts to respect by finding neologisms equivalent to their Russian-English counterparts. For example, "droogs" are "drugos"; "moloko" is "moloco"; "devotchka" is "devosca"; the famous verb "viddy" is "videar"; and so on.

The difference between the non-standard language in A Clockwork Orange and non-standard in the other works examined is that the latter are marks of sociolects which are indicative of the social standings, societal power and identity of particular communities. The same does not happen with Alex's idiolect, an inventive literary creation alive in the universe of the novel only and not spoken by real speakers of the real world.

It thus follows that the translation of this novel is probably more at ease to find suitable equivalents to non-standard insofar as it does not have to bear social realities into consideration.

\section{Conclusion}

To conclude, we would like to focus on the last translation examined, that of A Clockwork Orange. The latter shows how a sufficient phonetic and morphological deviation from standard language in Portuguese is possible in order to achieve the full foreignising, non-standard effect of the source text. However, when the raw material 
is people's actual language from the real world, as is the case with the other works examined, translating modes of speaking and expression becomes a highly more sensitive, more ideological process insofar as the translator is forced (or not) to deviate from a standard, societal linguistic norm in order to convey a non-standard, non-normalised, "marginal" discourse which in itself is a mark of disparate lifestyles, values and behaviours. To evoke the figure of Caliban again, to whom Prospero taught how to speak, translating dialect is translating the language of the "Other" which has been burdened with the linguistic measure of standard language against which deviant discourse will never measure up.

Translation therefore becomes a sensitive, ideological process which reflects the translator's own views on how to value marginal discourse, the discourse of the "Other", by choosing a domesticated or a foreignising translation. This is a highly symbolic process in the sense that Bourdieu employs "symbolic capital" and attaches it to standard language - it implies respecting or deviating from the "prestige, charisma, charm" (Bourdieu 1991, 128) which form a kind of capital unconsciously recognised by society as legitimate and therefore superior. This is why it is revelatory that the translation of Lady Chatterley's Lover shies away from rendering dialect, although it does not eliminate it altogether - is it because it considered dialectal, non-standard features to be so minor that they should be glossed over so as not to contaminate the literary merit of the translated novel? Could it be that the social and/or political mores of the time prevented the translator to accurately depict the linguistic deviation from standard language? Or could it be because the translator was simply trying to avoid exposing the translated novel to ridicule, as can happen when rendering dialect into a target language?

The "cultural demarcation principles" (Doorslaer et al. 2015) which have guided the translation of non-standard British English into European Portuguese are set on avoiding to commit to any vernacular which could give away a particular community of speakers. In fact, most translations seem to have decided to convey the "communicative slant" of the source texts by following Hatim \& Mason's 
aforementioned remark: "simply modifying the standard itself." (Hatim \& Mason 1997, 89) In the source texts, non-standard language was marked by both regional and social markers (Lady Chatterley's Lover being a prime example) and deviation from standard meant systemic differences at syntactical, phonological and lexical levels. The target language chooses colloquial, non-elite markers rather than regional or geographical and tends to prefer the aforementioned "supranational colloquial style" instead of indexing specific linguistic markers to specific social groups - which would be a difficult task anyway, as demonstrated, for example, by the fuzzy social parameters that govern the use of você. By modifying and manipulating the linguistic resources of standard itself, the translations examined achieved a colloquial style (colloquial vocabulary, phonetic contractions, forms of address) which somehow preserved the non-elite discourse of the source text. This option also meant minimal deviation from standard and thus shows the ideological sensitivity of the translation process when dealing with non-standard language.

The choice of translating non-standard by fundamentally resorting to a colloquial style is entirely understandable as the complexity of heteroglossia in British English, due to different political, social and geographical realities, cannot be compared to that of European Portuguese. The full range of non-standard variation is therefore quite difficult to convey in the realm of translated works. That is why the translation strategies employed in the Portuguese rendition of 1984 are relevant - by cleverly resorting to pragmatic manipulation of forms of address to compensate for the heavily socially marked, non-standard features of the source text, the Portuguese rendition of 1984 shows it is possible to alter Standard by manipulating pragmatics. A translation close to the source text in every aspect of its linguistic level (ie, phonology, syntax and lexicon, the main areas where discourse deviated from Standard) is rendered unnecessary.

Most translations examined therefore kept a closer proximity to standard language than the source texts. This can mean two things: firstly, it can show a pervasive ideological thrust, which is that a target language with minimal deviation from standard is enough to 
convey the socio-pragmatic linguistic features of the source language and their respective encoded social meanings. However, it can also mean that European Portuguese is not capable of encompassing the wide heteroglossic variation present in other languages, namely British English, because the social and geographical differences of both countries necessarily entail different linguistic communities and discursive identities. Silva, for example, points out the effort to drive European Portuguese more homogenously towards Standard after the Carnation Revolution in 1974, which would have been responsible for the weaker dialectal continuum of European Portuguese as opposed to Brazilian Portuguese:

O PB [português brasileiro] configura uma situação de diglossia - uma clara discrepância (ainda) existente entre a norma tradicional idealizada e prescritiva e a norma (ou normas) real(is) dos grandes centros urbanos - e apresenta um grande continuum dialetal (...) ao passo que o PE [português europeu] se caracteriza por uma crescente estandardização a partir da revolução democrática de 1974. (Silva 2011, 574)

It is of course not realistic to think that the effort towards Standard has turned European Portuguese into a homogeneous language, or that it supressed the dialectal variation found in the country. On the other hand, it bears repeating that British English is used by four different nations comprising the United Kingdom. One could say that British English is "internally" pluricentric due to its political organisation. Given the vastly different political backdrops, linguistic variety in British English and in the European Portuguese cannot but operate in different ways, but the case of European Portuguese might also be a case of not granting enough attention to non-standard varieties, and not necessarily diminished dialectal vigour.

This begs the questions of the limits of translation and language itself - how far can social meanings be encoded in a target language that seems to not be prepared to encode them because it operates and codifies social meanings in different modes (through forms of address, for example)? Or is it just that heteroglossia in European 
Portuguese has not yet had the attention it deserves as it is a sensitive topic?

Examining the translation of non-standard British English in European Portuguese thus leaves more questions unanswered than those it can indeed answer but we should note that representing, mediating and ultimately translating marginal, non-normalised realities, including non-standard language, is a sensitive task which plays with core, ideological values and which is always going to be arduous.

Nothing seems more apt than to evoke The Tempest again, this time the words of Prospero, as incentive to the work ahead: "...be cheerful/ And think of each thing well".

\section{Bibliography \\ I) Primary Sources}

Burgess, Anthony. A Clockwork Orange. Introduction by John Walsh. Banned Book Series, 2007 (1962).

--- A Laranja Mecânica. Trans. Vasco Gato. Lisboa: Alfaguara. Penguin Random House, 2016.

Eliot, T. S. The Waste Land and Other Poems. London: Faber and Faber, 1940 (1922).

--- A Terra Devastada. Trans. Gualter Cunha. Lisboa: Relógio d'Água, 1999.

Lawrence, D. H.. Lady Chatterley's Lover. London: Penguin, 1960 (1928).

--- O Amante de Lady Chatterley. Trans. António R. Salvador. Lisboa: Relógio d'Água, 2016. [the translation is a reprint of the 1975 edition by Delfos] Orwell, George. 1984. London: Penguin, 1987 (1949).

--- 1984. Trans. Ana Luísa Faria. Lisboa: Antígona, 2007.

\section{II) Secondary Sources}

Blackledge, Adrian \& Angela Creese (eds.) Heteroglossia as Practice and Pedagogy. Dordrecht: Springer, 2014. 
Berman, Antoine. "Translation and the Trials of the Foreign". The Translation Studies Reader. Ed. L. Venuti. London and New York: Routledge, 2000. 284- 297.

Boléo, Manuel de Paiva. Estudos de Linguística Portuguesa e Românica. Vol. 1. Coimbra: Acta Universitatis Conimbrigensis, 1974.

Bourdieu, Pierre. Language and Symbolic Power. Edited and introduced by John B. Thompson. Cambridge: Polity Press, 1991.

Brown, Roger \& Albert Gilman. "The Pronouns of Power and Solidarity". Readings in the Sociology of Language. Ed. J. A. Fishman. The Hague and Paris: Mouton, 1968. 252- 275.

Cintra, Luís Filipe Lindley. "Nova Proposta de Classificação dos Dialectos GalegoPortugueses". Boletim de Filologia, tomo XXII, fascs. 1 e 2, 1970: 81-116

--- Sobre "Formas de Tratamento" na Lingua Portuguesa. $2^{\text {a }}$ ed. Lisboa: Livros Horizonte, 1986.

Clyne, Michael. Pluricentric Languages: Differing Norms in Different Nations. Berlin/New York: Mouton de Gruyter, 1992.

Cristie, Chris. "Politeness in the Gendered Construction of Character: an Analysis of Dialect-Use in D.H. Lawrence's Lady Chatterley's Lover". Quaderns de Filologia. Estudis Lingüistics, vol. XII, 2007: 109-128.

Crystal, David. English as a Global Language. Cambridge: Cambridge University Press, 2003.

---. A Dictionary of Linguistics and Phonetics. Oxford: Blackwell, 2008.

Cuesta, Pilar Vázquez \& Maria Mendes da Luz. Gramática da Língua Portuguesa. Lisboa: Edições 70, 1971.

Cunha, Celso \& Luís Filipe Lindley Cintra. Nova Gramática do Português Contemporâneo. Lisboa: Edições Sá da Costa, 1984.

Doorslaer, Luc van, Peter Flynn \& Joep Leerssen (eds.) Interconnecting Translation Studies and Imagology. Amsterdam/Philadelphia: John Benjamins, 2015.

Duarte, Isabel Margarida. "Formas de Tratamento em Português: Entre Léxico e Discurso". Matraga, v. 18, n 28, 2011: 84-110.

Erkazanci-Durmus, Hilal. "A Critical Sociolinguistic Approach to Translating Marginal Voices: the Case of Turkish Translations". Translating Dialects and Languages of Minorities. Challenges and Solutions. Ed. F. M. Federici. Bern: Peter Lang, 2011. 21- 30. 
Fairclough, Norman. "The Appropriacy of 'Appropriateness'". Critical Language Awareness. Ed. N. Fairclough. London/New York: Longman, 1992. 33-56.

--- Language and Power. London: Longman, 2001.

Ferreira, Manuela Barros, Ernestina Carrilho, Maria Lobo, João Saramago \& Luísa Segura da Cruz. "Variação Linguística: Perspectiva Dialectológica". Introdução à Linguística Geral e Portuguesa. Eds. Isabel Hub Faria, Inês Duarte \& Carlos A. M. Gouveia. Lisboa: Caminho, 1996. 479-502.

Ghassempur, Susanne. "Fuckin'Hell! Dublin Soul Goes German: a Functional Approach to the Translation of 'Fuck' in Roddy Doyle's The Commitments". Translating Dialects and Languages of Minorities. Challenges and Solutions. Ed. F. M. Federici. Bern: Peter Lang, 2011. 49-64.

Gouveia, Carlos A. M. "As Dimensões da Mudança no Uso das Formas de Tratamento em Português Europeu". O Fascínio da Linguagem. Eds. Isabel Margarida Duarte \& Fátima Oliveira. Porto: Faculdade de Letras da Universidade do Porto, 2008. 91-100.

Hatim, Basil \& Ian Mason. The Translator as Communicator. London: Routledge, 1997.

Hughes, Arthur, Peter Trudgill \& Dominic Watt. English Accents and Dialects. London: Routledge, 2012.

Jansen, Hanne. "Bel Paese or Spaghetti noir? The Image of Italy in Contemporary Italian Fiction Translated into Danish". Interconnecting Translation Studies and Imagology. Eds. Luc van Doorslaer, Peter Flynn \& Joep Leerssen. Amsterdam. Philadelphia: John Benjamins, 2015. 163-180.

Javitch, Daniel (ed.) The Book of the Courtier. The Singleton Translation. London/ New York: Norton Critical Editions, 2002 [1528].

Lambert, J.. "Le sous-titrage et la question des traductions: rapport sur une enquête". Übersetzungwissenschaft: Ergebnisse und Perspektiven. Festschrift für W.Wilss zum 65. Eds R.Arntz \& G.Thome Geburtstag. Tübingen: Narr, 1990. 228-238.

Leith, Dick. A Social History of English. London: Routledge, 1997.

Leith, Richard. "Dialogue and Dialect in D. H. Lawrence". Style 14(3), 1980: 245-258.

Mills, Sara. English Politeness and Social Class. Cambridge: Cambridge University Press, 2017. 
Milroy, Lesley. "Standard English and Language Ideology in Britain and the United States." Standard English. The Widening Debate. Eds. Tony Bex \& Richard. J. Watts. New York: Routledge, 1999. 173-206.

Oliveira, Fernão de. Gramática da Linguagem Portuguesa. Introdução, leitura actualizada e notas de Maria Leonor Carvalhão Buescu. Lisboa: Imprensa Nacional Casa da Moeda, 1975 [1536].

Oliveira, Sandi Michelle de. "Winning Friends and Influencing People Abroad: Using Native Speakers' Communicative Strategies". Intercultural Communication Studies IV(1), 1994: 25-52.

Shaw, Bernard. Pigmalião. Trans. Mário César de Abreu. Lisboa: Publicações Europa-América, [s.d.]

Teyssier, Paul. Manual de Língua Portuguesa (Portugal - Brasil). Coimbra: Coimbra Editora, 1989.

Silva, Augusto Soares da. "Para a Abordagem Socioletométrica do Pluricentrismo do Português Europeu e Brasileiro: Dos Indicadores Lexicais aos Construcionais e Atitudinais". Línguas Pluricêntricas: Variação Linguística e Dimensões Sociocognitivas. Eds. Augusto Soares da Silva, Amadeu Torres \& Miguel Gonçalves. Braga: Publs. da Faculdade de Filosofia, Universidade Católica Portuguesa, 2011. 573-592.

Toury, Gideon. Descriptive Translation Studies - and Beyond. Amsterdam/ Philadelphia: John Benjamins, 1995.

Trudgill, Peter. "Standard English: What is isn't". Standard English. The Widening Debate. Eds. Tony Bex \& Richard J. Watts. New York: Routledge, 1999. 117-128.

Venuti, Lawrence. The Translator's Invisibility: A History of Translation. London \& New York: Routledge, 2008.

Watts, Richard. "The Social Construction of Standard English: Grammar Writers as a Discourse Community". Standard English. The Widening Debate. Eds. Tony Bex \& Richard J. Watts. New York: Routledge, 1999. 40-68. 